\title{
Production of Lightweight Bricks Using Saw Dust
}

\author{
Mushtaq Ahmed $^{1 *}$, Mahzuz HMA ${ }^{1}$, Rakash Kumer Mondal ${ }^{2}$, Md. Sal-Shabil ${ }^{2}$
}

${ }^{1}$ Faculty, Department of Civil and Environmental Engineering, Shahjalal University of Science and Technology, Sylhet- 3114, Bangladesh
${ }^{2}$ Ex-Student, Department of Civil and Environmental Engineering, Shahjalal University of Science and Technology, Sylhet- 3114, Bangladesh

DOI: $10.36347 /$ sjet.2020.v08i07.003

| Received: 13.07.2020 | Accepted: 20.07.2020 | Published: 24.07.2020

*Corresponding author: Mushtaq Ahmed

Abstract

Original Research Article

Clay bricks are widely used for building construction in Bangladesh. Due to rapid urbanization, use of clay bricks is increasing exponentially which leads to air pollution, as well as huge degradation of topsoil from the agricultural lands. Besides, clay bricks increase dead load of structure as they are heavy. In order to minimize these problems, techniques must be innovated for production of low-cost lightweight and eco-friendly bricks. In this study, an attempt was taken to assess the potentiality of locally available saw dust instead of clay to produce lightweight eco-friendly bricks. Total 16 different ratios of cement, saw dust and sand have been taken to prepare samples of saw dust bricks. Compressive strength, unit weight, water absorption rate, fire sensibility and cost of production per brick were analyzed for each type of bricks and compared. The result shows that the compressive strength of bricks was satisfactory for lower percentage of saw- dust. Unit weight of saw dust bricks were reduced by $2-42.8 \%$ than that of clay brick and water absorption rate was very low. There was no significant difference between strength of burnt and the unburnt saw dust bricks. Price of saw dust bricks is not higher than that of clay bricks.

Keywords: Brick, Saw dust, Lightweight, Compressive strength, Water absorption

Copyright @ 2020: This is an open-access article distributed under the terms of the Creative Commons Attribution license which permits unrestricted use, distribution, and reproduction in any medium for non-commercial use (NonCommercial, or CC-BY-NC) provided the original author and source are credited.

\section{INTRODUCTION}

Brick is one of the oldest construction materials that were first found in Southern Turkey and around Jericho (a Palestinian city in the West Bank) back to $7000 \mathrm{BC}$ and the first brick was manufactured with mud by sun drying. More recent examples like ruins of Harappa, Buhen and Mohenjo-Daro also exist. The Romans first successfully introduced kiln fired brick around the Roman Empire [1]. In accordance to the ancient legacy even now construction without bricks is nearly impossible. Different types of bricks are now available, such as burnt clay bricks, sand lime bricks, concrete bricks, fly ash clay bricks and mechanical bricks etc. [2].

Due to geographic position and geological condition of Bangladesh, bricks are more popular than stone in construction field. Bangladesh lies in the deltaic plain of Ganges and Brahmaputra. Thus, there is no significant source of stone in Bangladesh. In most cases stones are imported from nearby countries. It requires huge transportation and other cost. Considering this high expense, brick is the effective alternative of rock in Bangladesh. Normally kiln burnt clay bricks are used in Bangladesh which causes many environmental hazards during their manufacturing process.
Because of the popularity of brick, a huge number of brick fields are developed in Bangladesh. Around 4500 brick kilns are operational in Bangladesh and about 9 billion bricks are produced every year [3]. Current technology for brick production consumes a large quantity of fuel such as coal, firewood and other biomasses [4]. About 1000 brick kilns are located in six nearby districts of Dhaka, which emit 23300 tons of $\mathrm{PM}_{2.5}$ (particulate matter), 15500 tons of sulfur dioxide $\left(\mathrm{SO}_{2}\right), 302000$ tons of carbon monoxide $(\mathrm{CO}), 6000$ tons of black carbon, and 1.8 million tons of carbon dioxide $\left(\mathrm{CO}_{2}\right)$ to produce 3.5 billion bricks per year [5] Another study showed that, carbon dioxide emission from brickfields was the highest in Chittagong [6].

Because of the huge production of clay bricks, every year a large amount of fertile topsoil is excavated to collect clay from a depth of about 1-2 meters of agricultural lands, which leads to land degradation [7]. If it continues, scarcity of cultivable lands will be severe at the near future.

A clay brick weighs 3 to $3.5 \mathrm{~kg}$. Usually the unit weight of bricks is considered as 120 pcf (1924 $\mathrm{kg} / \mathrm{m}^{3}$ ) in structural analysis [8], which is huge. Because 
of this heavy weight, it certainly increases the dead load on the structure as well as inertia force [9], which have adverse effect during earthquake. Heavy weight also increases the material cost. Considering this heavy weight and environment pollution, the present study was conducted to manufacture light weight bricks using different ratios of cement, saw dust and sand.

About 3.34 million tons of wood waste is generated per year during wood conversion from 4800 sawmills in Bangladesh, where 0.99 million tons of waste is saw dust [10]. This huge amount of saw dust has no significant use except a small portion as fuel for cooking. So, use of saw dust as brick component would be beneficial from the point of waste minimization too.

Some works have been found which are like the field of this study. Kayali [11] conducted a study for manufacturing bricks using fly ash. The manufacturing process, technique and equipment were used as for clay bricks. The manufactured bricks were found $28 \%$ lighter than clay bricks and compressive strength was found higher than $40 \mathrm{MPa}$.

Turgut and Algin [12] concluded in their study that compressive strength, flexural strength, unit weight, ultrasonic pulse velocity (UPV) and water absorption values of manufactured bricks from limestone dust and wood sawdust satisfy the relevant international standards. They had also shown that the compressive strength is inversely related with amount of wood saw dust.

Kadir and Mohajerani [13] assessed potential of constructing fired clay bricks from cigarette butts. The result explores that the density of fired bricks reduced by $8-30 \%$ depending on the percentage of cigarette butts. The compressive strength of brick was found to be 12.57, 5.22 and 3.00 MPa for 2.5, 5.0 and $10 \%$ of cigarette butts respectively.

A study [14] was conducted to produce lightweight bricks using natural wastes like orange peels and coconut wastes. It was found that the compressive strengths of such kind of bricks were gradually decreased with relative increment of waste materials. Figure- 1 shows the variation of strength with respect to waste used.

Mahzuz HMA, Ahmed IU, Singha KK, Sharmin R [15] used styrofoam to produce lightweight bricks in his research work. Styrofoam bricks decreases dead load on structures, but styrofoam is highly fire sensitive (melting point is $210-249^{\circ} \mathrm{C}$ ).

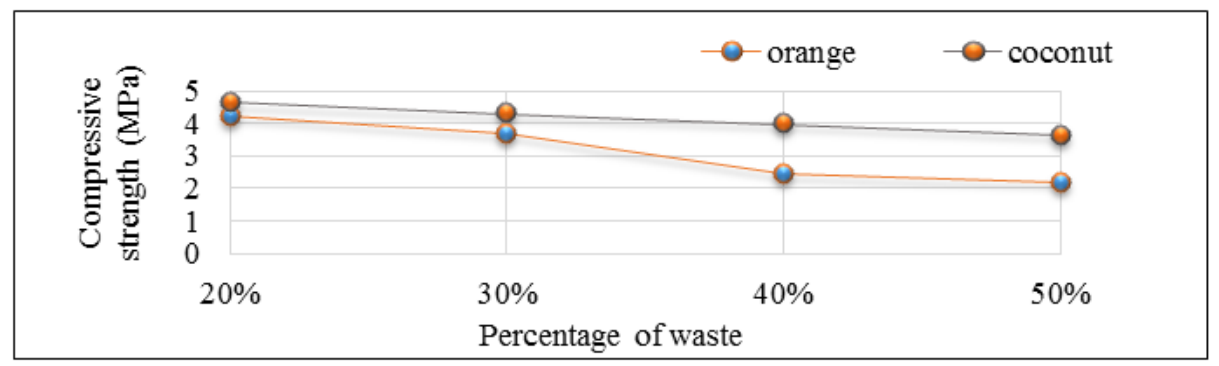

Fig-1: Compressive strength of bricks with different percentage of natural wastes (Source: Arshad, 2014)

\section{MATERIALS AND METHOD Materials}

The study was conducted in Sylhet city of Bangladesh. The materials that have been used in this study are cement, saw dust and sand. Saw dust was collected from the nearby sawmills of Sylhet. Portland
Limestone Cement (Clinker 65-79\%, Limestone 21$35 \%$, Gypsum 0-5\% and BDS EN 197-1:2003 CEM II/B-L $42.5 \mathrm{~N}$ ) was used as binding material. After collecting the materials basic physical properties were examined. The physical properties of saw dust and sand are given bellow in Table-1.

Table-1: Physical properties of saw dust and sand

\begin{tabular}{|c|c|c|}
\hline Material & FM & Unit Weight \\
\hline Saw dust & 2.37 & $187.56 \mathrm{~kg} / \mathrm{m}^{3}$ \\
\hline Sand & 2.30 & $1570 \mathrm{~kg} / \mathrm{m}^{3}$ \\
\hline
\end{tabular}

Based on volume of materials (cement, saw dust and sand) 16 different mix ratios were considered to prepare specimens, among them 5 ratios were without sand and other 11 ratios were with sand. So, samples were divided into two categories:

- Type-1: Bricks made by saw dust and cement (cement: saw dust)
- Type-2: Bricks made by saw dust, cement and sand (cement: saw dust: sand)

The mix ratios are shown in Table- 1 and Table2. The Water- Cement Ratio (w/c) of 0.485 was used for all mix ratios. 
Table- 2: Different mix ratios of type- 1 saw dust bricks (sand excluded)

\begin{tabular}{|c|c|}
\hline $\begin{array}{c}\text { Mix Ratio } \\
\text { No. }\end{array}$ & $\begin{array}{c}\text { Mix Ratio } \\
\text { (cement: saw dust: sand) }\end{array}$ \\
\hline 1 & $1: 1: 0$ \\
\hline 2 & $1: 1.5: 0$ \\
\hline 3 & $1: 2: 0$ \\
\hline 4 & $1: 2.5: 0$ \\
\hline 5 & $1: 3: 0$ \\
\hline
\end{tabular}

Table- 3: Different mix ratios of type- 2 saw dust bricks (sand included)

\begin{tabular}{|c|c|}
\hline $\begin{array}{c}\text { Mix Ratio } \\
\text { No. }\end{array}$ & $\begin{array}{c}\text { Mix Ratio } \\
\text { (cement: saw dust: sand) }\end{array}$ \\
\hline 6 & $1: 3.9: 1.3$ \\
\hline 7 & $1: 3.3: 1.3$ \\
\hline 8 & $1: 3: 1.4$ \\
\hline 9 & $1: 2.7: 1.4$ \\
\hline 10 & $1: 2.5: 1.4$ \\
\hline 11 & $1: 2.3: 1.4$ \\
\hline 12 & $1: 1.9: 1.4$ \\
\hline 13 & $1: 1.8: 1.3$ \\
\hline 14 & $1: 1.7: 1.3$ \\
\hline 15 & $1: 1.3: 1.3$ \\
\hline 16 & $1: 1: 1.5$ \\
\hline
\end{tabular}

\section{Mixing and molding}

Proper mixing and measurement of the materials are very important to obtain the desired strength of the specimen. Mixing of material was conducted manually and the consistency of the mixing was maintained. Wooden molds were used, dimension of which was $241.3 \mathrm{~mm} \times 114.3 \mathrm{~mm} \times 69.85 \mathrm{~mm}$, as for conventional clay bricks in Bangladesh. Three samples for each ratio have been made. The manufactured bricks were kept in a room temperature for 2 days before unmolding. Figure- 2 shows the bricks after unmolding.

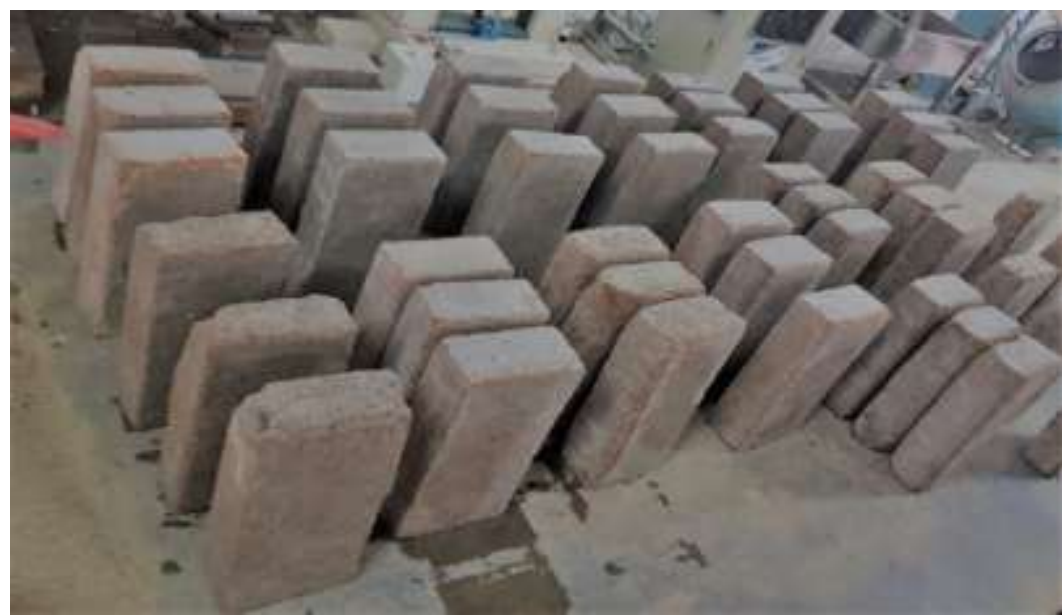

Fig-2: Saw dust bricks after unmolding

\section{Curing}

Curing was done after unmolding the bricks as cement was used as binding material. 28 days long curing process was conducted in room temperature. During the curing time, weight of the bricks was measured after 7, 14, 21 and 28 days to determine their water absorption rate.

\section{Compressive strength test}

Compressive strength has been tested in two phases: one was before burning the bricks and another was after burning. Compressive strength test was done according to the ASTM standard C67-03a [16]. 3 brick samples were tested from each mix ratio and then the corresponding results were averaged to obtain the final compressive strength. The readings were taken after formation of cracks on the brick surface. Some failure modes are shown in figure- 3 . 

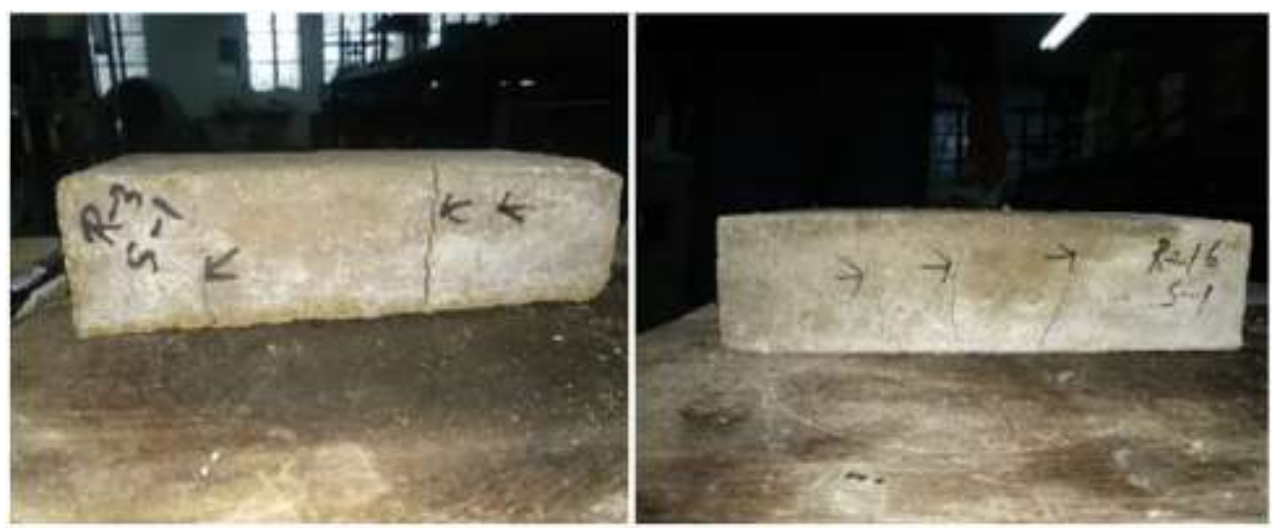

Fig- 3: Cracks on the bricks at the time of failure

\section{Water absorption test}

After unmolding, the dry weight of the saw dust bricks was measured. Then the saw dust bricks were submerged into curing tank. Using the recorded weights of the saw dust bricks after 7, 14, 21 and 28 days, the absorption rates were determined for all 16 mix ratios according to ASTM C20 method [17].

\section{Fire sensibility test}

As wood is a flammable material, Digital Muffle Furnace was used to check fire sensitivity of the bricks. Ignition temperature of wood placed in an oven is $700^{\circ} \mathrm{F}\left(371.1^{\circ} \mathrm{C}\right)$. At this temperature wood catches fire almost immediately. At oven temperatures of $450^{\circ}$ $500^{\circ} \mathrm{F}\left(232.2^{\circ} \mathrm{C}-260^{\circ} \mathrm{C}\right)$, the wood gradually chars and usually ignites after several hours [18]. Considering these facts temperature at muffle furnace was kept $350^{\circ} \mathrm{C}$. The inner textures of the burnt and unburnt bricks are shown in figures- 4 and 5 respectively.

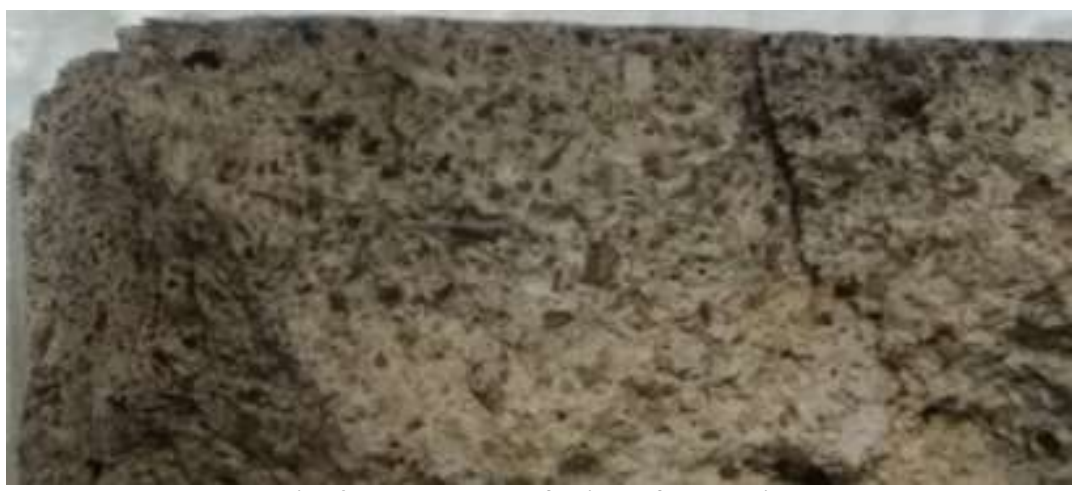

Fig- 4: Inner texture of bricks after burning

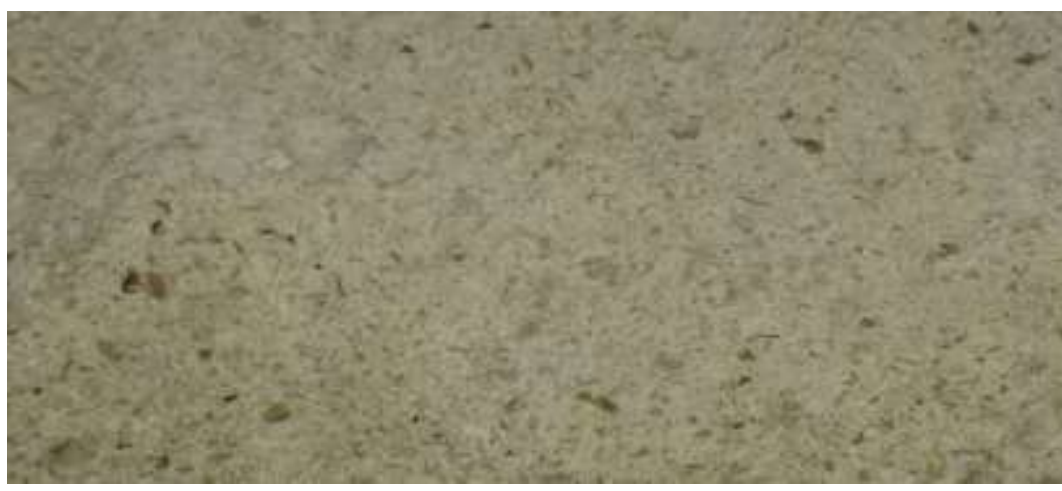

Fig-5: Inner texture of unburnt brick

\section{Brick standards}

For comparing the results of different tests some standards for bricks are discussed here. There are two standards available in Bangladesh: one is Standard of Local Government Engineering Department of Bangladesh (LGED Standard, 2005) and another is Bangladesh Standard (BDS 208:2009). The standard of LGED is given below in table- 4 . 
Table-4: LGED standard of bricks

\begin{tabular}{|l|c|c|}
\hline \multicolumn{1}{|c|}{ Type of bricks } & $\begin{array}{c}\text { Minimum compressive strength of brick } \\
(\mathbf{M P a})\end{array}$ & $\begin{array}{c}\text { Maximum water absorption rate } \\
(\%)\end{array}$ \\
\hline First class & 13.7 & $20 \%$ \\
\hline Picket (Jhama) & 16.7 & $15 \%$ \\
\hline $\begin{array}{l}\text { First-class machine-made } \\
\text { bricks }\end{array}$ & 20.6 & $10 \%$ \\
\hline Perforated & 20.6 & $12 \%$ \\
\hline Clinker & 55.1 & $15 \%$ \\
\hline
\end{tabular}

According to Bangladesh Standard there are three grades of bricks: S Grade, A Grade and B Grade, minimum compressive strengths of which are 24.13 $\mathrm{MPa}, 15.17 \mathrm{MPa}$ and $10.34 \mathrm{MPa}$ respectively [19]. ASTM C62 (2006) refers the standard of building bricks for three weather conditions: Severe Weather (SW), Moderate Weather (MW) and Normal Weather (NW). Table- 5 presents the ASTM classification of brick. Brick standard according to IS 1077:1992 (IS, 1992 ) is given in table- 6 .

Table-5: ASTM C62 classification of bricks [20]

\begin{tabular}{|c|c|c|}
\hline \multirow{2}{*}{ Grade of bricks } & \multicolumn{3}{|c|}{ Minimum Compressive Strength (MPa) } \\
\cline { 2 - 3 } & Average of five bricks & Individual \\
\hline SW & 20.7 & 17.2 \\
\hline MW & 17.2 & 15.2 \\
\hline NW & 10.3 & 8.6 \\
\hline
\end{tabular}

Table-6: IS standard of bricks [21]

\begin{tabular}{|c|c|c|}
\hline Classification of bricks & Average strength (MPa) & Maximum water absorption (\%) \\
\hline 35 & 35 & \multirow{10}{*}{$\begin{array}{c}20 \% \\
(12.5-15 \% \text { for higher classes })\end{array}$} \\
\hline 30 & 30 & \\
\hline 25 & 25 & \\
\hline 20 & 20 & \\
\hline 17.5 & 17.5 & \\
\hline 15 & 15 & \\
\hline 12.5 & 12.5 & \\
\hline 10 & 10 & \\
\hline 7.5 & 7.5 & \\
\hline 5 & 5 & \\
\hline
\end{tabular}

\section{RESULT AND DISCUSSION}

An overview of the total findings is given in figure- 6 .

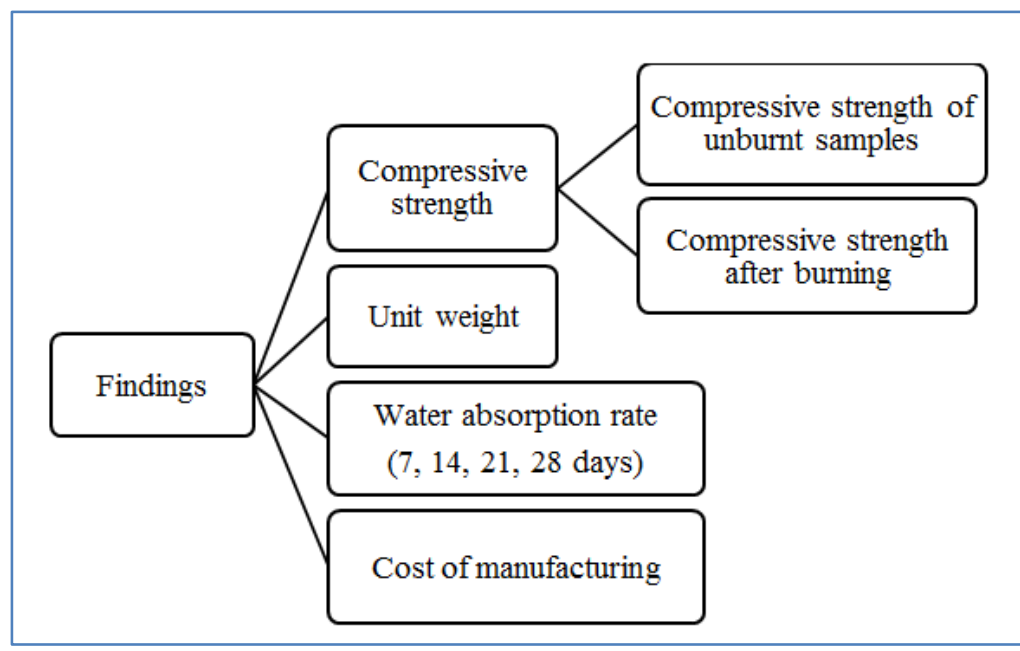

Fig-6: Findings of the study 


\section{Compressive strength and unit weight}

Table- 7 shows the comparison of compressive strengths of burnt and unburnt type- 1 bricks and their unit weights. As predicted, the compressive strength as well as the unit weight for both burnt and unburnt type-
1 bricks decreases gradually with the increase of the percentage of saw dust. The strength of burnt bricks is lesser than the unburnt bricks, but the variation of strengths are not as high as anticipated.

Table-7: Comparative compressive strength and unit weight of burnt and unburnt type-1 bricks

\begin{tabular}{|c|c|c|c|}
\hline \multirow{2}{*}{ Mix Ratio no. } & \multicolumn{2}{|c|}{ Compressive strength (MPa) } & \multirow{2}{*}{ Unit weight $\left(\mathbf{k g} / \mathbf{m}^{\mathbf{3}}\right)$} \\
\cline { 2 - 3 } & Unburnt & Burnt & \\
\hline $\mathbf{1}$ & 11.65 & 11.01 & 1327 \\
\hline $\mathbf{2}$ & 8.65 & 7.57 & 1243 \\
\hline $\mathbf{3}$ & 7.07 & 6.97 & 1230 \\
\hline $\mathbf{4}$ & 5.57 & 4.57 & 1153 \\
\hline $\mathbf{5}$ & 3.18 & 3.15 & 1129 \\
\hline
\end{tabular}

Table- 7 shows that the compressive strength of Ratio- 1 satisfies the ASTM C62 (minimum- 10.3 $\mathrm{MPa}$ ), BDS 208:2009 (minimum- 10.7 MPa) and IS 1077 (minimum- $5 \mathrm{MPa}$ ) standards. Ratios- 2, 3 and 4 satisfy the IS 1077 standard. Generally, unit weight of bricks varies from $1500-2000 \mathrm{Kg} / \mathrm{m}^{3}$. The result reveals that type- 1 saw dust brick is lighter than the normal clay brick.
Table- 8 shows the comparative strength of burnt and unburnt type- 2 bricks and the relative unit weights. Type- 2 bricks do not follow proper pattern of increasing or decreasing the strength and unit weight as was seen for type- 1 .

Table-8: Comparative compressive strength and unit weight of burnt and unburnt type- 2 bricks

\begin{tabular}{|c|c|c|c|}
\hline \multirow{2}{*}{ Mix Ratio no. } & \multicolumn{2}{|c|}{ Compressive strength (MPa) } & \multirow{2}{*}{ Unit weight $\left(\mathbf{k g} / \mathbf{m}^{\mathbf{3}}\right)$} \\
\cline { 2 - 3 } & Unburnt & Burnt & \\
\hline $\mathbf{6}$ & 3.16 & 3.08 & 1250 \\
\hline $\mathbf{7}$ & 3.28 & 2.42 & 1292 \\
\hline $\mathbf{8}$ & 1.85 & 1.56 & 1313 \\
\hline $\mathbf{9}$ & 2.06 & 1.56 & 1328 \\
\hline $\mathbf{1 0}$ & 2.42 & 1.98 & 1344 \\
\hline $\mathbf{1 1}$ & 3.71 & 3.21 & 1380 \\
\hline $\mathbf{1 2}$ & 7.29 & 5.14 & 1406 \\
\hline $\mathbf{1 3}$ & 6.14 & 5.85 & 1391 \\
\hline $\mathbf{1 4}$ & 6.86 & 5.00 & 1359 \\
\hline $\mathbf{1 5}$ & 10.93 & 7.57 & 1505 \\
\hline $\mathbf{1 6}$ & 10.29 & 10.15 & 1547 \\
\hline
\end{tabular}

For Ratio- 6 to 11 the unit weight of type- 2 bricks is lesser than the unit weight of normal clay bricks, but the strength does not satisfy the standard. Strength of saw dust bricks satisfy IS- 1077 standard in case of ratios- 12 to 16 . Finally, ratios 15 and 16 satisfy ASTM C62, BDS 208:2009 and IS- 1077 standards, but the unit weight is nearly like minimum unit weight of normal clay bricks. From the table- 8 it was also observed that the strength of type- 2 burnt bricks is lesser than the unburnt bricks, although there are no massive differences.

Depending upon strength, ratio- 1 was found the best (11.65 MPa and 11.01 $\mathrm{MPa}$ for unburnt and burnt bricks respectively) and the worst was ratio- 8 (1.85 $\mathrm{MPa}$ and 1.56 $\mathrm{MPa}$ for unburnt and burnt bricks respectively).
Considering the weight of conventional clay brick is approximately $3 \mathrm{~kg}$ and thus unit weight is $1562.5 \mathrm{~kg} / \mathrm{m}^{3}$, the result shows that the unit weights of saw dust bricks were reduced by $2-42.8 \%$, depending on different mixed ratios.

It was observed during compressive strength test that saw dust bricks were not failed suddenly; rather they were squeezed shortly before failure. So, saw dust bricks can absorb certain shock and they are not as brittle as conventional clay bricks.

\section{Water absorption rate}

The water absorption rate varies for different mix ratios. Figures- 7 and 8 show the water absorption rate of type- 1 and type- 2 saw dust bricks after 7,14 , 21 and 28 days respectively. 


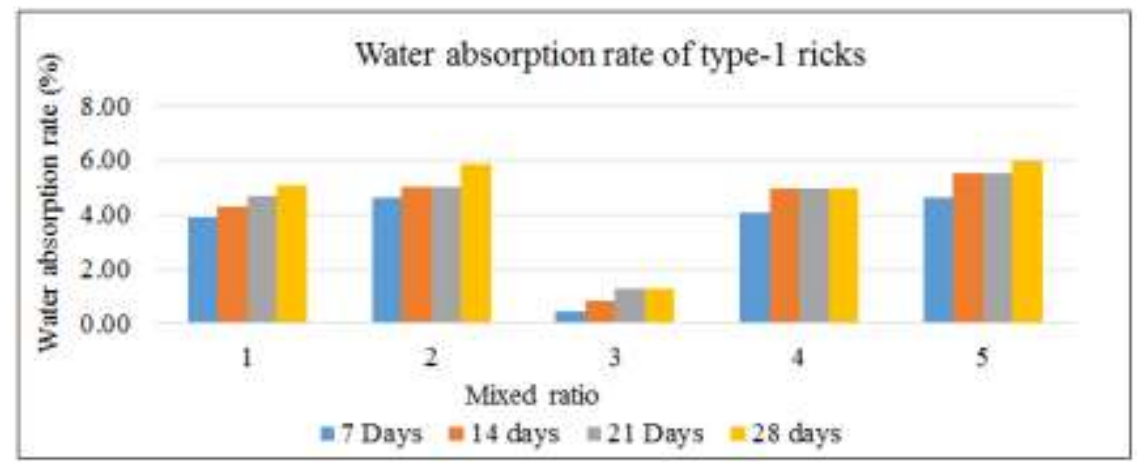

Fig-7: Comparative water absorption rate for type- 1 bricks

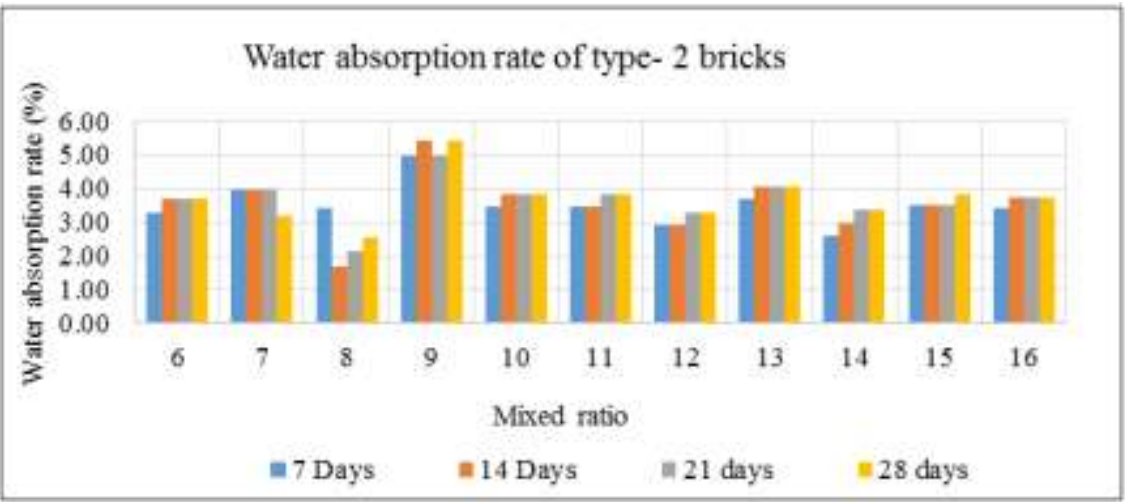

Fig- 8: Comparative water absorption rate for type- 2 bricks

The water absorption rate of saw dust bricks varies from $0.42 \%$ to $5.99 \%$ where the absorption rate of conventional clay bricks varies from $15 \%$ to $20 \%$ [23]. The experiment indicates that the water absorption rate of saw dust brick is significantly lower. Among 16 different ratios, ratio- 3 shows the lowest absorption rate and ratio- 5 shows the highest. No specific pattern was observed in case of water absorption rate for different mix ratios.

Saw dust bricks were kept under water in curing tank for 28 days. After that some of them were kept in normal weather of laboratory for a long period. But no visible decomposition was observed.

\section{Material cost}

For calculation of material cost of saw dust bricks local market prices (Sylhet region) for year 2019 were considered. Figure- 9 shows the material cost of all ratios in US Dollar ( 1 USD $=84.73$ BDT on 01/12/19). The cost for ratios- 1 to 5 is in decreasing order and from ratios- 6 to 16 is in increasing order.

The maximum and minimum cost of saw dust bricks were 0.152 and 0.057 USD respectively. Average wholesale price of conventional bricks at local market was found 0.128 USD. So, except for ratio- 1, prices of saw dust bricks were less than conventional clay bricks.

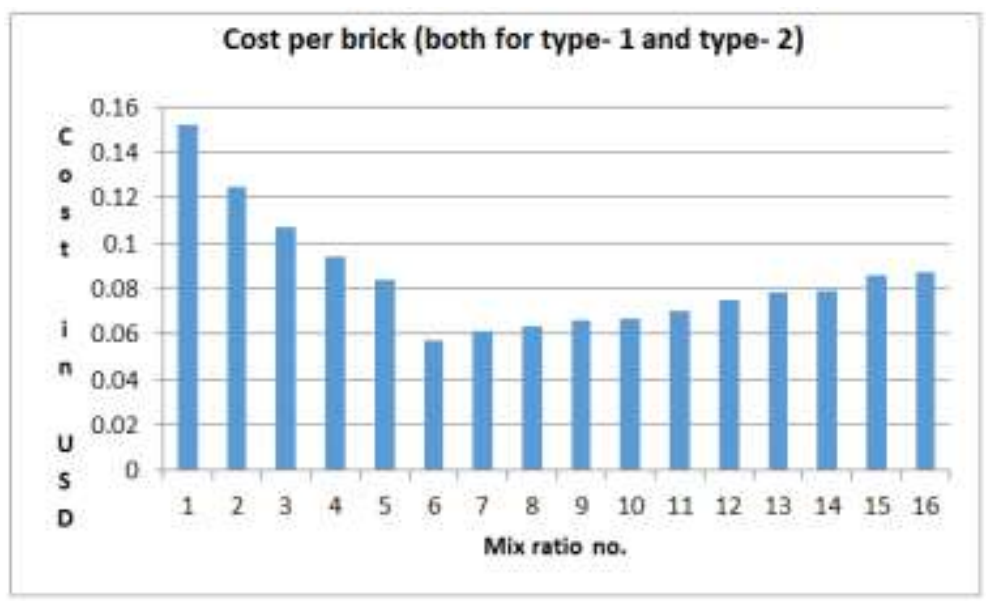

Fig-9: Material cost for bricks 


\section{CONCLUSIONS}

Compressive strengths of 9 (out of 16) mix ratios were found satisfactory according to different standards. Table- 9 gives an overview on their different acceptable properties.

Table-9: The ratios which satisfied the standards

\begin{tabular}{|c|c|c|c|c|c|}
\hline $\begin{array}{l}\text { Mix ratio } \\
\text { nos. }\end{array}$ & $\begin{array}{c}\text { Ratio } \\
\text { (cement: saw } \\
\text { dust: sand) }\end{array}$ & $\begin{array}{c}\text { Compressive } \\
\text { strength of unburnt } \\
\text { bricks that satisfied } \\
\text { standards: }\end{array}$ & $\begin{array}{l}\text { Unit weight } \\
\qquad\left(\mathrm{Kg} / \mathrm{m}^{\mathbf{3}}\right)\end{array}$ & $\begin{array}{c}\text { Water } \\
\text { absorption rate } \\
(\%)\end{array}$ & Cost comparison \\
\hline 1 & $1: 1: 0$ & ASTM, IS, BDS & $\begin{array}{l}\text { Less than clay } \\
\text { bricks }\end{array}$ & \multirow{9}{*}{$\begin{array}{l}\text { Below } 6 \%, \\
\text { which is much } \\
\text { less than clay } \\
\text { bricks }\end{array}$} & As clay bricks \\
\hline 2 & $1: 1.5: 0$ & $\begin{array}{l}\text { IS and ASTM (for } \\
\text { individual brick) }\end{array}$ & $\begin{array}{l}\text { Less than clay } \\
\text { bricks }\end{array}$ & & $\begin{array}{c}\text { less than clay } \\
\text { bricks }\end{array}$ \\
\hline 3 & $1: 2: 0$ & IS & $\begin{array}{c}\text { Less than clay } \\
\text { bricks }\end{array}$ & & $\begin{array}{c}\text { less than clay } \\
\text { bricks }\end{array}$ \\
\hline 4 & $1: 2.5: 0$ & IS & $\begin{array}{l}\text { Less than clay } \\
\text { bricks }\end{array}$ & & $\begin{array}{l}\text { less than clay } \\
\text { bricks }\end{array}$ \\
\hline 12 & 1:1.9:1.4 & IS & $\begin{array}{l}\text { Less than clay } \\
\text { bricks }\end{array}$ & & $\begin{array}{l}\text { less than clay } \\
\text { bricks }\end{array}$ \\
\hline 13 & $1: 1.8: 1.3$ & IS & $\begin{array}{c}\text { Less than clay } \\
\text { bricks }\end{array}$ & & $\begin{array}{c}\text { less than clay } \\
\text { bricks }\end{array}$ \\
\hline 14 & 1:1.7:1.3 & IS & $\begin{array}{c}\text { Less than clay } \\
\text { bricks }\end{array}$ & & $\begin{array}{c}\text { less than clay } \\
\text { bricks }\end{array}$ \\
\hline 15 & $1: 1.3: 1.3$ & ASTM, IS, BDS & $\begin{array}{c}\text { Like minimum } \\
\text { value of clay bricks }\end{array}$ & & $\begin{array}{c}\text { less than clay } \\
\text { bricks }\end{array}$ \\
\hline 16 & $1: 1: 1.5$ & ASTM, IS, BDS & $\begin{array}{c}\text { Like minimum } \\
\text { value of clay bricks }\end{array}$ & & $\begin{array}{l}\text { less than clay } \\
\text { bricks }\end{array}$ \\
\hline
\end{tabular}

It is seen that bricks of ratios- 1, 15 and 16 satisfy all the standards for strength, although bricks of ratios- 15 and 16 are not lighter than clay bricks. They absorb water much less clay bricks and their costs are also similar or less than clay bricks. Bricks of ratios- 2 , $3,4,12,13$ and 14 have less compressive strength, but satisfactory according to IS standard. They are lighter and cheaper than clay bricks; absorb water much less than clay bricks.

\section{According to the study, it can be concluded that}

- Saw dust bricks have satisfactory compressive strength. So, these bricks can be used for non-load bearing walls or lightly loaded other members.

- Compressive strength of saw dust bricks varies for different mix ratios. It decreases with the increase of saw dust.

- There were no significant differences between the strengths of burnt and unburnt saw dust bricks.

- Saw dust bricks with satisfactory compressive strength are usually lighter than clay bricks. So, use of these bricks in building can reduce the dead load.

- Water absorption capacity of saw dust bricks are much less than clay bricks. These bricks will absorb less moisture if are used in building. It can reduce possibility of damping, as well as increasing extra dead load. Cost of saw dust bricks is similar or less than clay bricks.
- Use of saw dust bricks can reduce air pollution and depletion of fertile topsoil. On the other hand, it is a way of saw dust waste management.

- Further study can be conducted on long term durability of saw dust bricks.

\section{ACKNOWLEDGEMENT}

The research was funded by the SUST Research Centre of Shahjalal University of Science and Technology, Sylhet, Bangladesh.

\section{REFERENCES}

1. The History of Bricks and Brickmaking. The Brick Directory. 2019. [cited 2019 Apr 25]. Available from:

http://brickdirectory.co.uk/html/brick_history.html.

2. Rodriguez J. 5 types of materials used for bricks. The Balance Small Business [Internet]. 01: 2019. [Cited 2019 Apr 25]. Available from: https://www.thebalancesmb.com/bricks-types-usesand-advantages-844819.

3. Darain KM, Rahman AB, Ahsan A, Islam AB, Yusuf B. Brick manufacturing practice in Bangladesh: A review of energy efficacy and air pollution scenarios. Journal of Hydrology and Environment Research. 2013;1(1):60.

4. Begum BA, Biswas SK, Markwitz A, Hopke PK. Identification of sources of fine and coarse particulate matter in Dhaka, Bangladesh. Aerosol and Air Quality Research. 2010;10(4):345-53. 
5. Guttikunda SK, Begum BA, Wadud Z. Particulate pollution from brick kiln clusters in the Greater Dhaka region, Bangladesh. Air Quality, Atmosphere \& Health. 2013 Jun 1;6(2):357-65.

6. Imran MA, Baten MA, Nahar BS, Morshed N. Carbon dioxide emission from brickfields around Bangladesh. International Journal of Agricultural Research, Innovation and Technology. 2014;4(2):70-5.

7. Das R. Causes and consequences of land degradation in and around the brick kilns of khejuri CD blocks over Coastal Medinipur in West Bengal. International Journal of Innovative Research and Development. 2015;4(2):285.

8. Hassoun MN, Al-Manaseer AA. Structural concrete: theory and design. 6th ed. New Jersey: John Willey \& Sons, INC. 2015.

9. Murty CVR. Learning earthquake design and construction 5. What are the seismic effects on structures?. Resonance. 2004 Oct 1;9(10):78-81.

10. Islam MA, Rahman MS, Bosunia AKMA, Lahiry AK. Present status and potentiality of the economic utilization of the sawmill residue and wastage in Bangladesh. Paper presented at the $35^{\text {th }}$ Annual Meeting of International Research Group on Wood Protection; Ljubljana, Slovenia; 2004 Jun 6-10.

11. Kayali O. High performance bricks from fly ash. InProceedings of the World of Coal Ash Conference, Lexinton, Kentucky 2005 Apr 11 (Vol. 11).

12. Turgut P, Algin HM. Limestone dust and wood sawdust as brick material. Building and Environment. 2007 Sep 1;42(9):3399-403.

13. Kadir AA, Mohajerani A. Possible utilization of cigarette butts in light-weight fired clay bricks. environments. 2010;3:7.

14. Arshad MS, Pawade PY. Reuse of natural waste material for making light weight bricks.
International Journal of Scientific \& Technology Research. 2014 Jun;3(6):49-53.

15. Mahzuz, HMA, Ahmed IU, Singha KK, Sharmin R. Production of styrofoam bricks using strengthening admixture. International Journal of Masonry Research and Innovation. Forthcoming. 2020.

16. ASTM International. ASTM Standard C67-03a, "Standard test methods for sampling and testing brick and structural clay tile". West Conshohocken, PA. 2003.

17. ASTM International. ASTM Standard C20, "Standard test methods for apparent porosity, water absorption, apparent specific gravity, and bulk density of burned refractory brick and shapes by boiling water". West Conshohocken, PA. 2010.

18. Halton B, editor in chief. Ignition temperature of wood. Fire Engineering (Magazine) [Internet]. 2019. [cited 2019 May 26]; 102(11). Available from:

https://www.fireengineering.com/articles/print/volu me-102/issue-11/features/ignition-temperature-ofwood.html.

19. Bangladesh Standards and Testing Institution (BSTI). BDS 208:2009, "Specification for common building clay bricks (3rd revision)". Tejgaon, Dhaka. 2009.

20. ASTM International. ASTM Standard C62, "Standard specification for building brick (solid masonry units made from clay or shale)". West Conshohocken, PA. 2006.

21. Bureau of Indian Standards (BIS). IS 1077, "Common burnt clay building bricks specifications". New Delhi.

22. Aziz MA. Engineering materials. Revised ed. Dhaka: Trans-World Book Company; 1995. 